Original Article

\title{
DYNAMICS OF NOSEMA APIS AND NOSEMA CERANAE CO-INFECTION SEASONALLY IN HONEY BEE (APIS MELLIFERA L.) COLONIES
}

\author{
Asli Özkırım* \\ Aygün Schiesser \\ Nevin Keskin \\ Hecettepe University, Ankara, Turkey \\ *corresponding author: asli.ozkirim@gmail.com \\ Received: 24 August 2017; accepted: 14 November 2018
}

Abstract

\begin{abstract}
Nosema apis is a pathogen spesific for the European honeybee, Apis mellifera L., while Nosema ceranae is specific for the Asian honeybee, Apis cerana. Turkey provides different environmental and host conditions for both Nosema species. The aim of the study is to determine the dynamic of $\boldsymbol{N}$. cerenae and $\boldsymbol{N}$. apis seasonal infection. A number of samples were collected from different apiaries between $2009-2016$ years. The samples were kept at $-20^{\circ} \mathrm{C}$ in the laboratory. Light microscopy was used for spore counting and molecular techniques were used to identify the Nosema species. The results showed that winter season had an impact on the type of Nosema as well as on infection rates. The number of $\boldsymbol{N}$. ceranae spores decreases significantly at low temperatures $\left(\leq 5^{\circ} \mathrm{C}\right)$. The winter period was found to be the main factor affecting nosema infection level and dominancy of Nosema ceranae. Furthermore, co-infection of both species is an indicator of the dynamics of $\boldsymbol{N}$. apis and $\boldsymbol{N}$. ceranae. This study suggests, that there is a dynamic prevalence among the Nosema species depending of the average winter temperature and not a replacement of $N$. apis by $N$. ceranae.
\end{abstract}

Keywords: Nosema apis, Nosema ceranae, co-infection, survey, Turkey

\section{INTRODUCTION}

Nosemosis is a common worldwide disease of adult honey bees (Apis melliferaL.) that is caused by microsporidia (OIE, 2008). Nosema apis was the only agent known to produce this disease in $A$. mellifera L. until Nosema ceranae was identified in this host in 2005 in Europe (Higes, Martín, \& Meana, 2006), and Taiwan (Huang et al., 2007). Originally, N. apis was assumed to be a pathogen specific for causing nosemosis in the European honeybee, $A$. mellifera L., while $N$. ceranae was specific for the Asian honeybee, Apis cerana (Fries et al., 1996). However, early cross-infection experiments demonstrated that $N$. apis could infect $A$. cerana and that $N$. ceranae infected $A$. mellifera L. (Fries, 2010). N. apis is considered as a low-prevalence infection of A. mellifera even though it occurs world-wide (Hornitzky, 2005; OIE, 2008). However, the $N$. ceranae-caused disease is considered as emergent that is posing a major threat to the health of individiual honey bees and/or whole bee colonies (Higes et al., 2010). N. ceranae is reported to be more prevalent than $N$. apis and $N$. apis may be replaced by $N$. ceranae in different regions of Europe (Klee et al., 2007; Paxton et al., 2007).

The virulence of $N$. apis and $N$. ceranae has been examined by means of artificial infection in laboratory conditions or measured through epidemiological surveys in several studies (Bourgeois et al., 2010; Burgher-MacLellan et al., 2010; Chaimanee, Warrit, \& Chantawannakul, 2010; Traver \& Fell, 2011). Gisder et al. (2010) and (Traver, Williams, \& Fell, 2012) referred to how climatic conditions affected the virulence of Nosema spp. and compared the hive sampling and seasonal activity of $N$. ceranae in honey bee colonies. However, those studies focused on the infection route and management of $N$. ceranae in hives rather than the comparison of $N$. cerenae and $N$. apis infections under different climatic and geographical conditions. The aim of the current study is to determine the dynamics of $N$. cerenae and $N$. apis seasonal infection and 
if there is of $N$. apis replaced by $N$. ceranae in Turkey.

\section{MATERIAL AND METHODS}

\section{Sampling Area}

Turkey is a convenient sampling area for the observation of different climatic and geographical conditions. It has characteristics of a small continent with a high level of such biodiversity richness as agriculture, forests, mountains, steppes, wetlands, coastal areas and seas. Turkey is situated within the Holoarctic floral kingdom. Only on the Anatolian Peninsula there are about 11000 plant species, whereas in the whole of Europe there are 12500 plant species. Beekeepers raise five different races of honeybees and their three ecotypes, A.m. anatoliaca (three ecotypes: adami, thrace and mugla), A. m. meda, A. m. caucasica, A.m.syriaca, and A. m. carnica (Kandemir \& Kence, 1995; Palmer, Smith, \& Kaftanoglu, 2000). Migratory beekeeping is common and may influence the transfer of $N$. apis and $N$. cerenea spores between different locations, but as this study aimed to determine the effect of different weather and geographical conditions on Nosema spp. spores, stationary apiaries were chosen for sampling in each provinces. During the past eight years, bee samples were collected from the different provinces (Fig. 1).

\section{Bee Samples}

Bee samples consisting of thirty adult bees were collected from different colonies in the seventy-two provinces of Turkey (Fig. 1). Four apiaries from province were visited to collect samples during 2009-2016. 4 Samplings were repeated four times each season, so an average of 1041 bee samples were collected randomly from the same provinces over the eight years. For a sample, thirty bees were collected from outer frames. Clinical signs were not considered for sampling. The different levels of spores were measured under the different conditions by using the same colonies in each provinces during the study.

\section{Nosema Analyses}

The samples were kept at $-20^{\circ} \mathrm{C}$ in the laboratory. Two diagnostic methods were applied at Hacettepe University/Bee Health Laboratory respectively. First a light microscopy method was used for detection infestation level (spore counting), and then a molecular method was used to identify the species. Fifteen bees were carefully dissected and homogenized in a mortar and mixed with $1 \mathrm{~mL}$ of water for each bee (15 mL totally). The homogenate was filtered by Whatman paper No.1. The filtered solution was centrifugated at $300 \mathrm{rpm} 15 \mathrm{~min}$. The supernatant was discarded and $30 \mathrm{~mL}$ of water was mixed with pellet, and. $0,1 \mathrm{~mL}$ of

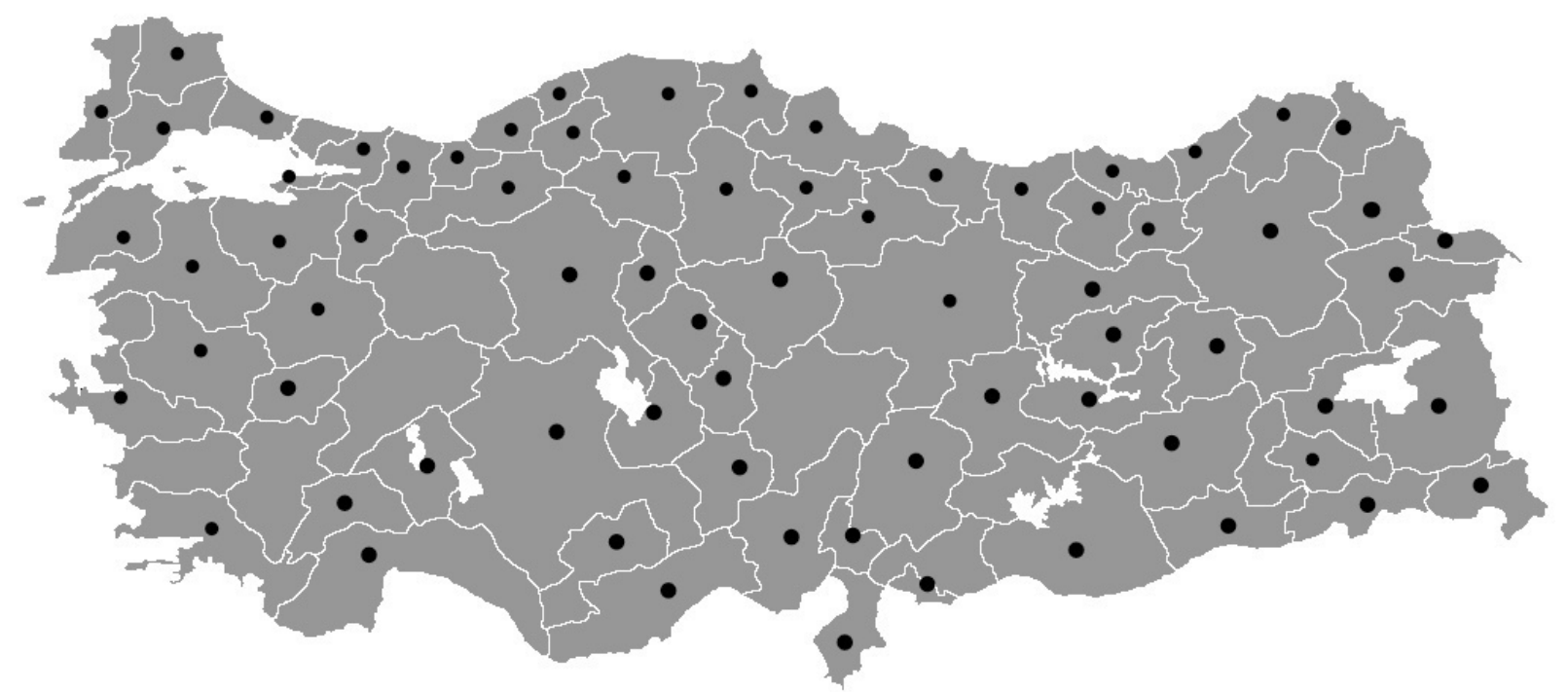

Fig. 1. Seventy-two Provinces from which bee samples were collected for the past eight years in Turkey. 
the solution was inoculated to the heamacytometer (Improved Neubauer) for counting the Nosema spores as described by Human et al., (2013).

Nosema DNA extraction was performed on fifteen bee homogenates with the DNeasy ${ }^{\oplus}$ Plant Mini Kit (Qiagen) following the Mini protocol for plant tissue (Fries et al., 2013). For multiplex Polymerase Chain Reaction (PCR), the primer combination suitable for the amplification of $N$. apis and $N$. ceranae was used as described by Fries et al. (2013). PCR products were resolved in a 1-2\% agarose gel with suitable size marker and then visualised through staining with ethidium bromide and photographing on a u/v transilluminator.

\section{Statistical Analyses}

The Pearson's Correlation Test (SPSS software programme v. 21) was used to compare the weather conditions and spore levels of Nosema species in each province during 2009-2016.

\section{RESULTS}

Monitoring lasted eight years and showed some interesting results concerning the distribution of Nosema ceranae and Nosema apis in Turkey. Three types of infection were found: single $N$. apis infection, single $N$. ceranae infection and co-infection with both species (mixed infection) in the samples. The minimum, maximum and average numbers of spores for both species between 2009 and 2016 аге summarized in Tab. 1. The positive rates (\%) of $N$. apis, N. ceranae and $N$. apis $+N$. ceranae in all samples between 2009 and 2016 are shown at Fig. 2.

The correlation between weather conditions and the infection levels of $N$. apis, $N$. ceranae, $N$. apis $+N$. ceranae was also found statistically positive by Pearson correlation coefficient Test (Tab. 2). The winter period was found to be the main factor affecting Nosema pathogens and dominancy of one over the other species. This correlation between winter temperatures from the lowest to the highest values and types of Nosema infection can be seen in Fig. 3-4.

There was a positive strong relation between the $N$. ceranae infection rate and winter temperatures, as the rate increased as temperatures. However, N. apis infection rate decreased as the winter temperatures increased. The distribution of different types of Nosema infection between 2009 and 2016 are shown on the map of Turkey (Fig. 5) according to weather conditions.

The minimum, maximum and average numbers of Nosema spores (x10 $\left.{ }^{6}\right)$

Table 1. for both species in the years 2009-2016

\begin{tabular}{ccccccccccc}
\hline & \multicolumn{3}{c}{ N. ceranae } & \multicolumn{3}{c}{ N. apis } & \multicolumn{3}{c}{ N.ceranae+N.apis } \\
\cline { 2 - 9 } Years & Min. & Max. & Average & Min. & Max. & Average & Min. & Max. & Average \\
\hline 2009 & 1.6 & 14 & $\mathbf{7 . 8}$ & 1.2 & 21 & $\mathbf{1 1 . 7}$ & 1.6 & 43.8 & $\mathbf{2 3 . 5}$ \\
2010 & 2.1 & 7.8 & $\mathbf{4 . 9}$ & 1.8 & 9.8 & $\mathbf{6 . 7}$ & 2.1 & 21.6 & $\mathbf{1 2 . 9}$ \\
2011 & 2.7 & 6.6 & $\mathbf{6 . 0}$ & 3.4 & 9.2 & $\mathbf{8 . 0}$ & 2.4 & 19.8 & $\mathbf{1 2 . 3}$ \\
2012 & 1.0 & 5.4 & $\mathbf{3 . 7}$ & 1.3 & 11 & $\mathbf{6 . 8}$ & 1.8 & 31.4 & $\mathbf{1 7 . 5}$ \\
2013 & 0.2 & 1.6 & $\mathbf{1 . 0}$ & $\mathbf{7 . 8}$ & 69.3 & $\mathbf{4 2 . 4}$ & 0.3 & 8.5 & $\mathbf{4 . 5}$ \\
2014 & 2.4 & 4.2 & $\mathbf{4 . 6}$ & 1.6 & 7.2 & $\mathbf{5 . 2}$ & 1.4 & 12.7 & $\mathbf{7 . 7}$ \\
2015 & 3.5 & 21.3 & $\mathbf{1 4 . 1}$ & 3.1 & 9.4 & $\mathbf{7 . 8}$ & 1.6 & 38.9 & $\mathbf{2 1 . 0}$ \\
2016 & 0.3 & 1.9 & $\mathbf{1 . 2}$ & 6.7 & 44 & $\mathbf{2 8 . 7}$ & 1.4 & 32.3 & $\mathbf{1 7 . 5}$ \\
\hline
\end{tabular}




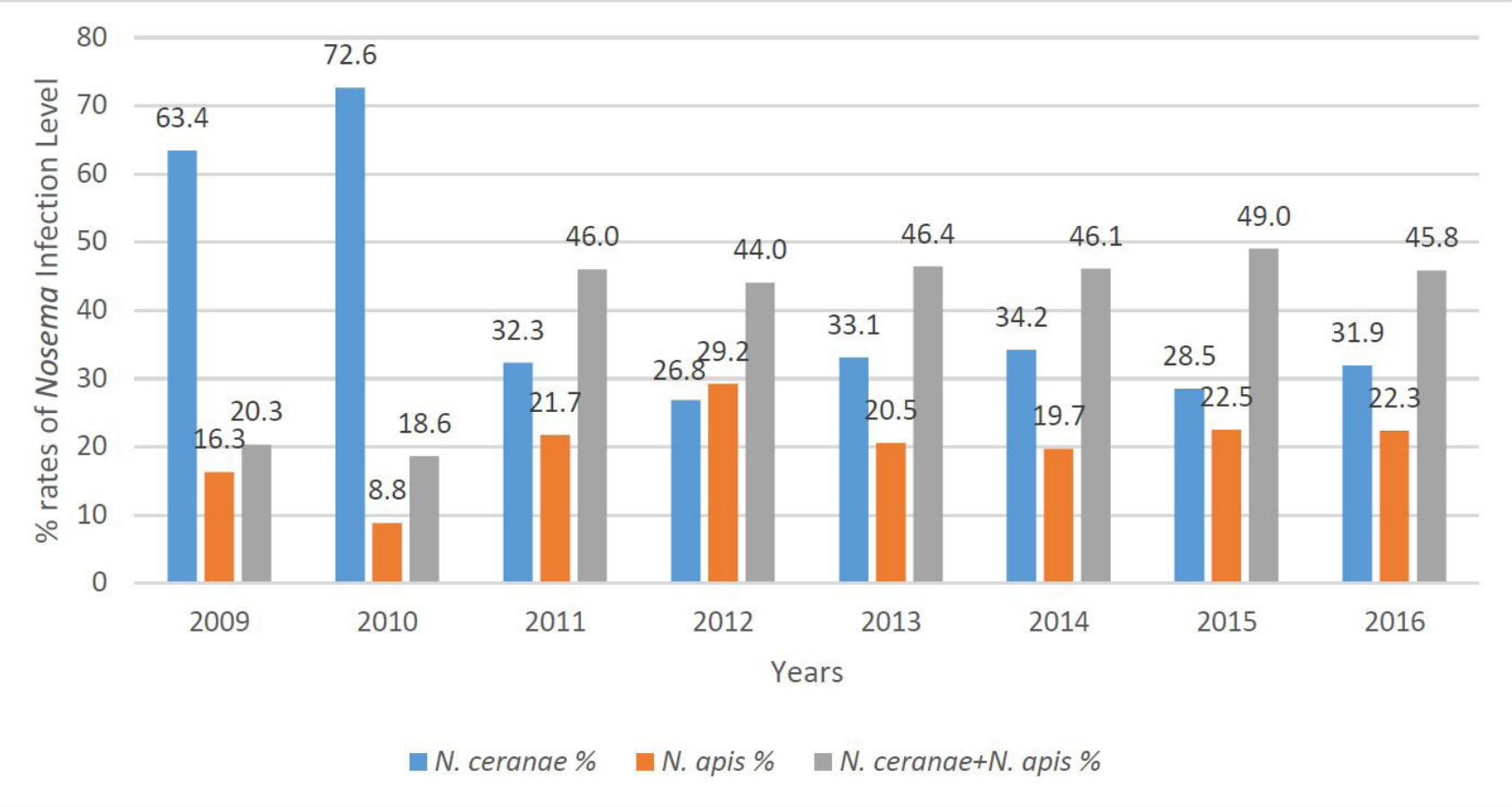

Fig. 2. The rates of $N$. apis, N. ceranae and $N$. apis $+N$. ceranae (co-infection) in all samples (\%) in the years 2009-2016.

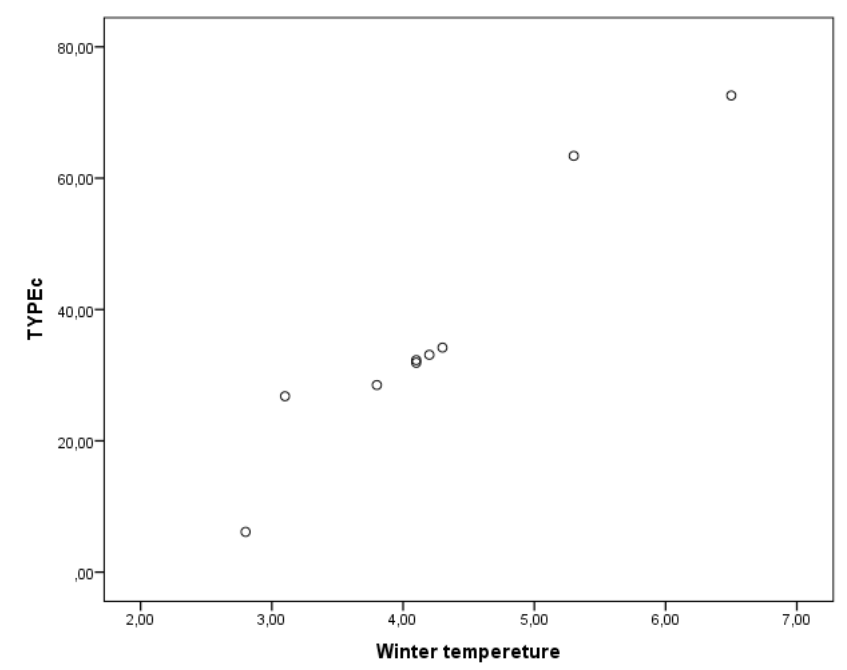

Fig. 3. The correlation between winter temperatures from the lowest to the highest values and $N$. ceranae infection level.

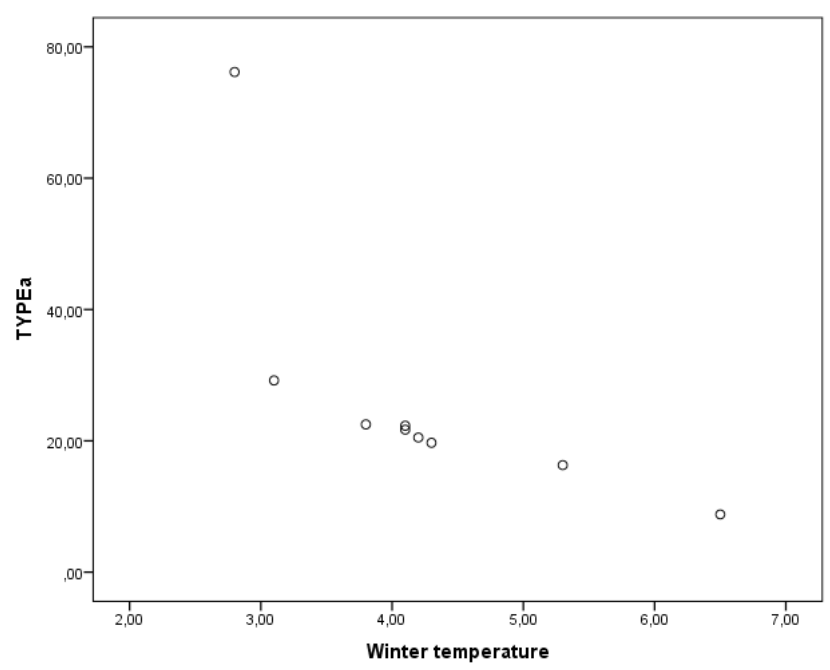

Fig. 4. The correlation between winter temperatures from the lowest to the highest values and N. apis infection level. 


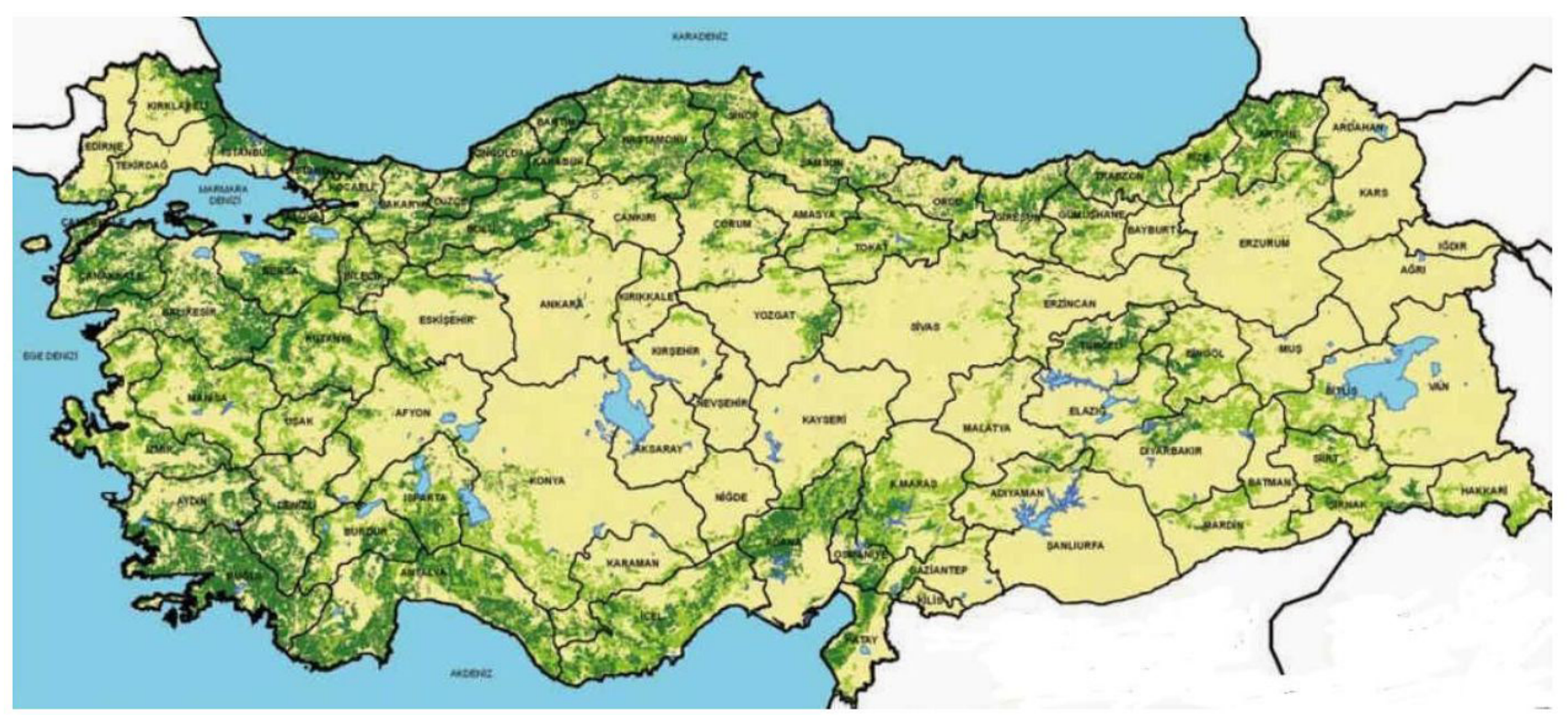

N.ceranae N. apis

Fig. 5. The distribution map of Nosema spp. in Turkey

Table 2.

Correlations between temperatures and spore numbers tested by Pearson Correlation Test

\begin{tabular}{ccccccc}
\hline & \multicolumn{2}{c}{ N. ceranae } & \multicolumn{2}{c}{ N. apis } & \multicolumn{3}{c}{ N. ceranae+N. apis } \\
\cline { 2 - 7 } & $\begin{array}{c}\text { Correlation } \\
\text { coefficient }\end{array}$ & p & $\begin{array}{c}\text { Correlation } \\
\text { coefficient }\end{array}$ & p & $\begin{array}{c}\text { Correlation } \\
\text { coefficient }\end{array}$ & p \\
\hline Winter & 0.961 & $<0.001^{*}$ & -0.710 & $0.032^{*}$ & -0.386 & 0.305 \\
Spring & 0.254 & 0.509 & -0.568 & 0.111 & 0.436 & 0.241 \\
Summer & -0.271 & 0.517 & 0.169 & 0.689 & 0.299 & 0.472 \\
Autumn & 0.035 & 0.934 & 0.210 & 0.617 & -0.147 & 0.728 \\
\hline
\end{tabular}

*Correlation is significant $P \leq 0.05$

\section{DISCUSSION}

Nosema ceranae is an emergent and potentially virulent pathogen of the honey bee (Apis mellifera) that has spread around the world in the last ten or so years (Paxton, 2010). In order to determine if there is a replacement between Nosema ceranae/Nosema apis, a long-term survey is needed for evaluating the situation. $N$. ceranae is also coming from Asian source populations, so Turkey is a critical location for trans- ferring $N$. ceranae to Europe and adaptation of the pathogen.

The results show that $N$. apis and $N$. ceranae have been found in Turkey at different rates since 2009. $N$. ceranae presents a different epidemiological pattern compared to $N$. apis. The co-infection was found mainly at high levels during the eight years in Turkey. Chen et al. (2009), Williams et al. (2014) and Charbonneau et al. (2016) revealed that both microsporidia produced single and mixed infections. 
Table 3.

The mean values of temperatures $\left({ }^{\circ} \mathrm{C}\right)$ seasonally between in $2009-2016$

\begin{tabular}{ccccc}
\hline Years & Winter & Spring & Summer & Autumn \\
\hline 2009 & 5.3 & 11.3 & 22.9 & 15.1 \\
2010 & 6.5 & 13.1 & 24.7 & 16.3 \\
2011 & 4.1 & 11.5 & 24.5 & 13.8 \\
2012 & 3.1 & 12.1 & 24.6 & 17.6 \\
2013 & 4.2 & 13.5 & 23.3 & 14.6 \\
2014 & 4.3 & 12.9 & 24.4 & 14.1 \\
2015 & 3.8 & 12.1 & 24.2 & 16.6 \\
2016 & 4.1 & 13.8 & 25.3 & 15.3 \\
\hline
\end{tabular}

In addition, both infection intensity and honey bee mortality have been reported to be significantly greater for $N$. ceranae than for either $N$. apis or mixed infections. The mixed infection resulted in mortality similar to $N$. apis parasitism and reduced spore intensity, possibly due to inter-specific competition. $N$. ceranae is can be detected throughout the year, while $N$. apis is observed mainly in spring and autumn time during rainy days and a high moisture level (Aydin et al., 2005). So, there is a relationship between $N$. apis and $N$. ceranae infections during the year. Several studies have reported the relationship of temperature and viability of spores (Fenoy et al., 2009; Higes, MartínHernández, \& Meana, 2010; Paxton, 2010; Retschnig et al., 2017; Whitaker, Szalanski, \& Kence, 2010). According to the data, especially winter conditions changed the rates of nosema infection level in colonies, so co-infection might indicator that the dominant Nosema species depends on the season and climatic conditions. For instance, when the winter temperatures decrease as in 2012 and 2015, N. apis has dominancy and cause a high level of infection. The winter period manages the type and levels of Nosema infection. So, "replacement" may not be the correct term to describe the change in the spread of $N$. apis and $N$. ceranae distribution around the world.

The co-infection level was low during the first two years (2009-2010) of the study, although it rose in the following years. This indicates that the years 2009 and 2010 years had the first and second highest temperature values of winter seasons (Tab. 3). N. ceranae was seen more frequently than either $N$. apis or co-infection. In paralell, the statistical analyses also revealed that there is also significant correlation between warm weather conditions in winter and high spore level and high prevalance of $N$. ceranae in bee colonies.

Location was found to indirectly affect the dynamics of $N$. apis, $N$. ceranae and co-infection, and the difference was again due to climatic conditions. Although the floral diversity and geographical conditions are different, if two provinces have the same climatic conditions, they have a similar results for Nosema type and infection level (e.g. Eskișehir and Kars in Fig. 5). This study suggests that a dynamic prevalence among the Nosema species depends on the average winter temperature and not the replacement of $N$. apis by $N$. ceranae.

\section{ACKNOWLEDGEMENTS}

This study was supported by the Hacettepe University Scientific Research Project Coordination Unit, project number: 01001601 003-163. We are also thankful to all Turkish Beekeepers who agreed to co-operate on the studies.

\section{REFERENCES}

Aydin, L., Cakmak, I., Gulegen, E., \& Wells, H. (2005). Honey bee nosema disease in the Republic of Turkey. Journal of Apicultural Research, 44(4), 196 - 


\section{J. APPC. SCL. VOL. Gi N NO. 12019}

\section{DOl: 10.1080/00218839.2005.11101179}

Bourgeois, A.L., Rinderer, T.E., Beaman, L.D., \& Danka, R.G. (2010). Genetic detection and quantification of Nosema apis and Nosema ceranae in the honey bee. Journal of Invertebrate Pathology, 103(1), 53-58. DOl: 10.1016/j.jip.2009.10.009

Burgher-MacLellan, K.L., Williams, G.R., Shutler, D., MacKenzie, K." Rogers, R.E. (2010). Optimization of Duplex Real-Time PCR with Meltingcurve Analysis for Detecting the Microsporidian Parasites Nosema apis and Nosema ceranae in Apis mellifera L. The Canadian Entomologist, 142(3), 271-283. DOl: 10.4039/ח10-010

Chaimanee, V., Warrit, N., \& Chantawannakul, P. (2010). Infections of Nosema ceranae in four different honeybee species. Journal of Invertebrate Pathology, 105(2), 207-210. DOl: 10.1016/j.jip.2010.06.005

Charbonneau, L.R., Hillier, N.K., \& Shutler, D. (2016). Effects of Nosema apis, N. ceranae, and coinfections on honey bee (Apis mellifera) learning and memory. Scientific Reports, 6, Article number: 22626. DOI: 10.1038/srep22626

Chen, Y., Evans, J.D \& Pettis, J.S. (2009). Asymmetrical coexistence of Nosema ceranae and Nosema apis in honey bees. Journal of Invertebrate Pathology, 101(3), 204-209. D0l: 10.1016/j.jp.2009.05.012

Coloss Workshop. (2009). Paper presented at the COLOSS Workshop "Nosema disease: lack of knowledge and work standardization" (COST ActionFA0803), Guadalajara.

Fenoy, S., Rueda, C., Higes, M., Martín-Hernández, R., Del Aguila, C. (2009). High-level resistance of Nosema ceranae, a parasite of the honeybee, to temperature and desiccation. Applied and Environmental Microbiology, 75(21), 6886-6889. DOl: 10.1128/AEM.01025-09

Fries, I., Chauzat, M.P., Chen, Y.P., Doublet, V., Genersch, E., Gisder, S., ... Williams, G.R. (2013). Standard methods for Nosema research, Journal of Apicultural Research, 52(1), 1-28, DOl: 10.3896/ IBRA.1.52.1.14
Fries, I. (2010). Nosema ceranae in European honey bees (Apis mellifera). Journal of Invertebrate Pathology, 103, S73-S79. DOl: 10.1016/j. jip.2009.06.017

Fries, I., Feng, F., da Silva, A., Slemenda, S.B., Pieniazek, N.J. (1996). Nosema ceranae ח. sp. (Microspora, Nosematidae), morphological and molecular characterization of a microsporidian parasite of the Asian honey bee Apis cerana (Hymenoptera, Apidae). European Journal of Protistology, 32(3), 356-365. https://doi.org/10.1016/S0932-4739(96)80059-9

Gisder, S., Hedtke, K., Möckel, N., Frielitz, M.C., Linde, A., Genersch, E. (2010). Five-year cohort study of Nosema spp. in Germany: does climate shape virulence and assertiveness of Nosema ceranae? Applied and Environmental Microbiology, 76(9), 3032-3038. DOI: 10.1128/AEM.03097-09

Higes, M., García-Palencia, P., Botías, C., Meana, A., Martín-Hernández, R. (2010). The differential development of microsporidia infecting worker honey bee (Apis mellifera) at increasing incubation temperature. Environmental Microbiology Reports, 2(6), 745-748. DOl: 10.1111/.17582229.2010.00170.x

Higes, M., Martín-Hernández, R., \& Meana, A. (2010). Nosema ceranae in Europe: an emergent type C nosemosis. Apidologie, 47(3), 375-392. DOl: 10.1051/ apido/2010019

Higes, M., Martín, R., \& Meana, A. (2006). Nosema ceranae, a new microsporidian parasite in honeybees in Europe. Journal of Invertebrate Pathology, 92(2), 93-95. DOl: 10.1016/j.jip.2006.02.005

Hornitzky, M. (2005). Nosema disease. Nosema disease literature review and survey of beekeepers, RIRDC Publication 05-005, 18.

Huang, W.F., Jiang, J.H., Chen, Y.W., \& Wang, C.H. (2007). A Nosema ceranae isolate from the honeybee Apis mellifera. Apidologie, 38(1), 30-37. DOl: 10.1051/ apido:2006054

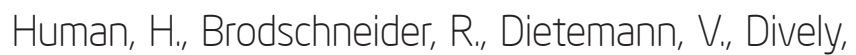
G., Ellis, J.D., Forsgren, E., ... Zhen, H. Q. (2013). 
Miscellaneous standard methods for Apis mellifera research, Journal of Apicultural Research, 52(4), 1-53, DOI: 10.3896/ IBRA.1.52.4.10

Kandemir, l., \& Kence, A. (1995). Allozyme variability in a central Anatolian honeybee (Apis mellifera L.) population. Apidologie, 26(6), 503-510.

Klee, J., Besana, A., Genersch, E., Gisder, S., Nanetti, A., Tam, D.Q.,... Kryger, P. (2007). Widespread dispersal of the microsporidian Nosema ceranae, an emergent pathogen of the western honey bee, Apis mellifera. Journal of Invertebrate Pathology, 96(1), 1-10. D0l: 10.1016/j.jp.2007.02.014

OlE. (2008). OlE Terrestrial Manual: Nosemosis of honey bees.

Palmer, M., Smith, D., \& Kaftanoglu, O. (2000). Brief communication. Turkish honeybees: genetic variation and evidence for a fourth lineage of Apis melliferamtDNA. Journal of Heredity, 97(1), 42-46.

Paxton, R.J. (2010). Does infection by Nosema ceranae cause "Colony Collapse Disorder" in honey bees (Apis mellifera)? Journal of Apicultural Research, 49(1), 80-84. DOI: 10.3896/IBRA.1.49.1.11

Paxton, R. J., Klee, J., Korpela, S., \& Fries, I. (2007). Nosema ceranae has infected Apis mellifera in Europe since at least 1998 and may be more virulent than Nosema apis. Apidologie, 38(6), 558-565. D0l: 10.1051/apido:2007037

Retschnig, G., Williams, G.R., Schneeberger, A., \& Neumann, P. (2017). Cold Ambient Temperature Promotes Nosema spp. Intensity in Honey Bees (Apis mellifera). Insects, 8(1), 20. DOl: 10.3390/ insects8010020

Traver, B.E., \& Fell, R.D. (2011). Prevalence and infection intensity of Nosema in honey bee (Apis mellifera L.) colonies in Virginia. Journal of Invertebrate Pathology, 1071), 43-49. DOl: 10.1016/j. jip.2011.02.003

Traver, B.E., Williams, M.R., \& Fell, R.D. (2012). Comparison of within hive sampling and seasonal activity of Nosema ceranae in honey bee colonies. Journal of Invertebrate Pathology, 109(2), 187-193. DOl: 10.1016/j.jip.2011.11.001

Turkish State Meteorological Service. (2009). Retrieved from https://mgm.gov.tr/FILES/ iklim/2009-yili-iklim-degerlendirmesi.pdf

Turkish State Meteorological Service. (2010). Retrieved from https://www.mgm.gov.tr/FILES/ iklim/2010-yili-iklim-degerlendirmesi.pdf

Turkish State Meteorological Service. (2011). Retrieved from https://www.mgm.gov.tr/FILES/ iklim/2011-yili-iklim-degerlendirmesi.pdf

Turkish State Meteorological Service. (2012). Retrieved from https://www.slideshare.net/ MustafaCamlica/2012-yilikklimdegerlendirmesi

Turkish State Meteorological Service. (2013). Retrieved from https://www.mgm.gov.tr/FILES/ iklim/2013-yili-iklim-degerlendirmesi.pdf

Turkish State Meteorological Service. (2015-2016). Retrieved from https://www.mgm.gov.tr/FILES/ iklim/yillikiklim/2015-2016-iklim-raporu.pdf

Whitaker, J., Szalanski, A. L., \& Kence, M. (2010). Molecular detection of Nosema ceranae and Nosema apis from Turkish honey bees. Apidologie, 42(2), 174-180. DOl: 10.1051/apido/2010045

Williams, G.R., Shutler, D., Burgher-MacLellan, K.L., \& Rogers, R.E.L. (2014). Infra-Population and Community Dynamics of the Parasites Nosema apis and Nosema ceranae, and Consequences for Honey Bee (Apis mellifera) Hosts. PLoS ONE 9(7): e99465. DOl: 10.1371/journal.pone.0099465 